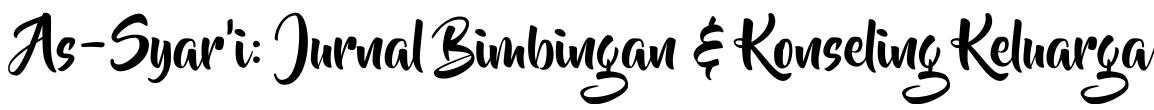

Volume 3 Nomor 1 (2021) 85-94 E-ISSN 2656-8152 P-ISSN 2656-4807

DOI: $10.47476 /$ as.v3i1.305

\section{Pengaruh Kreativitas Guru terhadap Motivasi Belajar Siswa di SMP YPN Bojonggede Bogor}

\author{
Marwati Ulfah \\ marwatiulfah98@gmail.com \\ Eda Laelasari \\ Fakultas Tarbiyah, IAI Nasional Laa Roiba \\ edalaelasariyasmin08@gmail.com \\ Ismail Mustaqiem \\ Fakultas Tarbiyah, IAI Nasional Laa Roiba \\ ismail.mustaqim17@gmail.com
}

\begin{abstract}
The research was in the background by viewing the fact on the ground that many students are often bored and students tend to passively listen to the teacher's descriptions because the less attractive lesson material transmission and the lack of communication between teacher and student in the lesson, resulting in a lack of student's learning motivation. With that background, researchers are intrigued to examine whether the creativity of a teacher in Islam is affecting students' learning motivation. The research was conducted in Junior High School YPN Bojonggede Bogor. The population is 103 students while the sample is 35 students. The study implemented correlation methods with research instruments using angkets for the creativity of the islamic religious education teacher and student learning motivation. Data was analyzed using product moment correlation techniques. Research shows $r$ calculated $=0.47>r$ table $=0.344$. Thus Ha is accepted and Ho rejected which means there is an influence in the creativity of teachers of Islam's education on students' learning motivation. So is the significance test with $t$ test show $t$ count $3.0590>$ $t$ table 2.0301. This means the influence of the creativity of the islamic religious education teacher on student learning motivation is a significant influence, while the contribution of the creativity of the islamic religious education teacher on the student's learning motivation is shown by KD (Coefficient of Determination) as 22.09\%.
\end{abstract}

Key words: Religious Teacher Creativity, Islamic Religious Education (IRE), Student Learning Motivation

\section{ABSTRAK}

Penelitian ini dilatar belakangi dengan melihat kenyataan dilapangan bahwa banyak dijumpai siswa sering merasa bosan dan siswa cenderung pasif mendengarkan uraian dari guru karena penyampaian materi pelajaran yang kurang menarik dan kurangnya komunikasi an tara guru dan siswa dalam pelajaran, sehingga mengakibatkan rendahnya motivasi belajar siswa. 


\section{As-Syari: Jurnal Binbbingan E̊ Konseling Keluarrga}

Volume 3 Nomor 1 (2021) 85-94 E-ISSN 2656-8152 P-ISSN 2656-4807

DOI: $10.47476 /$ as.v3i1.305

Dengan latar belakang tersebut, peneliti tertarik untuk meneliti apakah terdapat pengaruh kreativitas guru pendidikan agama Islam terhadap motivasi belajar siswa. Penelitian dilakukan di SMP YPN Bojonggede Bogor. Populasi dalam 103 siswa sedangkan sampelnya 35 siswa. Penelitian ini menerapkan metode korelasi dengan instrumen penelitian menggunakan angket untuk kreativitas guru pendidikan agama Islam dan motivasi belajar siswa. Data dianalisis menggunakan teknik korelasi Product Moment. Hasil penelitian menunjukkan $r$ hitung $=0,47>r$ tabel $=0,344$. Dengan demikian maka Ha diterima dan Ho ditolak yang berarti ada pengaruh kreativitas guru pendidikan agama Islam terhadap motivasi belajar siswa. Begitu juga uji signifikansi dengan uji t memperlihatkan thitung 3,0590 > ttabel 2,0301. Ini berarti pengaruh kreativitas guru pendidikan agama Islam terhadap motivasi belajar siswa adalah pengaruh yang signifikan, sedangkan kontribusi kreativitas guru pendidikan agama Islam terhadap motivasi belajar siswa ditunjukkan oleh KD (Koefiensi Determinasi) sebesar 22,09\%.

Kata kunci: Kreativitas Guru Agama, Pendidikan Agama Islam (PAI), Motivasi Belajar Siswa

\section{PENDAHULUAN}

Dunia pendidikan merupakan satu hal yang tidak ada habisnya untuk diperbincangkan. Mulai dari pendidik, peserta didik, materi dan semuanya selalu menjadi bahan untuk meningkatkan kualitas pendidikan itu sendiri. Pendidikan merupakan suatu usaha agar manusia dapat mengembangkan potensi dirinya melalui proses pembelajaran yang dikenal dan diakui oleh masyarakat. Hal ini dijelaskan dalam UU Republik Indonesia No. 20 Tahun 2003 tentang Sistem Pendidikan Nasional, BAB I Pasal 1 :

"Pendidikan adalah usaha sadar dan terencana untuk mewujudkan suasana belajar dan proses pembelajaran agar peserta didik secara aktif mengembangkan potensi dirinya untuk memiliki kekuatan spiritual keagamaan, pengendalian diri, kepribadian, kecerdasan, akhlak mulia, serta keterampilan yang diperlukan dirinya, masyarakat, bangsa dan negara (Undang-undang Republik Indonesia No. 20 Tahun 2003 tentang Sistem Pendidikan Nasional)."

Guru memegang peranan besar dalam proses belajar mengajar di sekolah, karena pembelajaran khususnya dalam Pendidikan Agama Islam tanpa pendampingan guru atau guru hanya duduk diam didalam kelas serta hanya memberikan perintah atau tugas saja tanpa memberikan materi pendalaman yang bersifat wawasan, aplikatif, dan menciptakan suasana pembelajaran yang canggih maka bisa menyebabkan pembelajaran Pendidikan Agama Islam hanya berhenti pada aspek kognitif saja. Padahal Pendidikan Agama Islam merupakan ajaran dan pedoman hidup untuk kebahagiaan dunia dan akhirat yang harus dilaksanakan bagi setiap siswa secara sadar, mandiri, dan konsisten dalam beribadah.

Dalam proses belajar mengajar guru mempunyai tugas untuk mendorong, membimbing, dan memberi fasilitas belajar bagi murid-murid untuk mencapai tujuan. Guru mempunyai tanggung jawab untuk melihat segala sesuatu yang terjadi dalam kelas untuk membantu proses perkembangan anak. Guru yang baik ialah guru yang melalui kegiatan mengajarnya mampu mengilhami murid-muridnya. Melalui kegiatan mengajar yang memberikan ilham, guru yang baik memberikan gagasan-gagasan yang besar, keinginan yang besar pada murid- 


\section{As-Syar'i: Jurual Bimbingan \&̌ Konseling Keluarge}

Volume 3 Nomor 1 (2021) 85-94 E-ISSN 2656-8152 P-ISSN 2656-4807

DOI: $10.47476 /$ as.v3i1.305

muridnya.

Dengan pentingnya kreativitas guru, sehingga melalui kegiatan kreativitas diharapkan akan membantu tercapainya tujuan pembelajaran. Seorang pendidik sudah selayaknya memiliki kreativitas yang tinggi, guna menciptakan proses pembelajaran yang tepat sehingga mencapai hasil yang optimal dari semua tujuan yang telah ditetapkan dalam pengajaran. Dengan kreativitas yang tinggi, guru dapat menciptakan suasana belajar yang efektif.

Dalam mengajar anak-anak memang tidak mudah, guru harus mengenal gaya belajar anak agar dapat menemukan apa yang terjadi dalam masalah belajar setiap anak didiknya. Apabila guru tidak kreatif dalam mengajar, maka yang terjadi adalah anak akan merasa bosan, malas, jenuh, dan tidak suka belajar. Padahal banyak diantara anak-anak yang senang dengan keadaan gurunya yang baik, kreatif, menarik, terampil dan tidak monoton. Namun rata-rata guru sekolah kurang mengenal anaknya baik dari segi rohaninya maupun dari segi jasmaninya.

Kenyataan dilapangan banyak dijumpai siswa sering merasa bosan dan siswa cenderung pasif mendengarkan uraian dari guru karena penyampaian materi pelajaran yang kurang menarik dan kurangnya komunikasi antara guru dan siswa dalam pelajaran, sehingga mengakibatkan rendahnya motivasi belajar siswa. Berdasarkan hal-hal yang telah diuraikan, penulis berkeinginan untuk meneliti tentang kreativitas guru terhadap motivasi belajar siswa. Pemilihan judul tersebut diharapkan mampu mengatasi problem yang sedang terjadi disekolah serta dapat meningkatkan kreativitas guru dalam pengajaran Pendidikan Agama Islam.

\section{KAJIAN TEORI}

\section{Motivasi Belajar Siswa}

Dalam pembahasan ini penulis akan menjelaskan apa itu motivasi belajar. Motivasi berasal dari kata motif, yang dapat diartikan sebagai daya upaya yang mendorong seseorang untuk melakukan sesuatu. Berdasarkan kamus besar bahasa indonesia motif adalah sebabsebab yang mendorong seseorang umtuk berbuat, dasar pikiran atau pendapat, sesuatu yang menjadi pokok (cerita atau gambaran dan sebagainya) (Hermawan Aksan, 2017).

Pengertian motivasi menurut Mc. Donald adalah perubahan energi dalam diri seseorang yang ditandai dengan munculnya "feeling" dan didahului dengan tanggapan terhadap adanya tujuan.8 Pengertian motivasi menurut M. Ngalim Purwanto adalah suatu pernyataan yang komplek di dalam suatu organisme yang mengarahkan tingkah laku terhadap suatu tujuan (goal) atau perangsang (incentive) (Sardiman,2006).

Macam-macam atau jenis-jenis motivasi dapat dilihat dari berbagai sudut pandang, yaitu :

a. Motivasi dilihat dari dasar pembentukannya

1) Motif-motif bawaan

Maksudnya motif yang dibawa sejak lahir, jadi motivasi itu ada tanpa dipelajari. Misalnya dorongan untuk makan, dorongan untuk minum, dorongan untuk belajar. Motif-motif ini 


\section{As-Syar'i: Jurnal Binbingan ६̨ Konseling Kelluargena}

Volume 3 Nomor 1 (2021) 85-94 E-ISSN 2656-8152 P-ISSN 2656-4807

DOI: $10.47476 /$ as.v3i1.305

seringkali disebut dengan motif- motif yang diisyaratkan secara biologis.

2) Motif-motif yang dipelajari Maksudnya motif yang timbul karena dipelajari. Misalnya dorongan untuk belajar suatu cabang ilmu pengetahuan, dorongan untuk mengajar sesuatu di dalam masyarakat. Motif-motif ini seringkali disebut dengan motifmotif yang diisyaratkan secara sosial (Sardiman, 2006).

b. Motivasi dilihat dari pembagiannya

1) Motif atau kebutuhan organis, meliputi misalnya: kebutuhan untuk minum, makan, bernapas, kebutuhan untuk istirahat

2) Motif-motif darurat. Yang termasuk dalam jenis ini antara lain: dorongan untuk menyelamatkan diri, dorongan untuk membalas, untuk berusaha. Jelasnya motif ini timbul karena rangsangan dari luar.

3) Motif-motif objektif. Dalam hal ini menyangkut kebutuhan untuk melakukan eksplorasi, untuk menaruh minat. Motif ini muncul karena dorongan untuk dapat menghadapi dunia luar secara efektif (Sardiman, 2006).

4) Motivasi dilihat dari jasmaniah dan rohaniah

5) Yang termasuk motivasi jasmaniah seperti misalnya : refleks, insting otomatis, hawa nafsu. Sedangkan yang termasuk motivasi rohaniah adalah kemauan.

c. Motivasi dilihat dari intrinsik dan ekstrinsik

1) Motivasi intrinsik

Motivasi intrinsik adalah motif- motif yang menjadi aktif atau berfungsinya tidak perlu dirangsang dari luar, karena dalam diri setiap individu sudah ada dorongan untuk melakukan sesuatu (Sardiman, 2006). Misalnya seseorang yang senang membaca, tidak usah ada yang menyuruh atau mendorongnya, ia sudah rajin membaca buku- buku untuk dibacanya.

2) Motivasi ekstrinsik

Motivasi ekstrinsik adalah motif-motif yang menjadi aktif atau berfungsinya karena adanya perangsang dari luar. Misalnya seseorang itu belajar, karena tahu besok paginya ada ujian dengan harapan mendapatkan nilai yang baik, sehingga akan dipuji temannya. Jadi yang penting bukan karena belajar ingin mengetahui sesuatu, tetapi ingin mendapatkan nilai yang baik, atau agar mendapatkan hadiah (Sardiman,2006: 89).

\section{Kreativitas Guru}

Profesi guru sebagai bidang pekerjaan khusus dituntut memiliki komitmen untuk meningkatkan mutu pendidikan salah satunya adalah dengan memiliki kreativitas. Dalam Kamus Besar Bahasa Indonesia, kreativitas diartikan sebagai "kemampuan untuk mencipta" atau "daya cipta" atau "perihal berkreasi" (Hermawan Aksan, 2017). Apabila arti dari kata kreativitas ini diartikan secara global dapat menyangkut dengan sesuatu yang sangat penting dalam kehidupan setiap manusia. Kreativitas juga berkaitan dengan potensi yang ada di dalam diri manusia yang dapat dimanfaatkan untuk mengubah kehidupan. Pada umumnya yang paling banyak dilakukan adalah melalui penataran, yaitu :

1) Penataran penyegaran.

2) Penataran peningkatan kualifikasi.

3) Penataran penjenjangan (Piet Sahartian, 1994).

Masih banyak lagi yang dapat dilakukan oleh guru untuk meningkatkan kualitas 


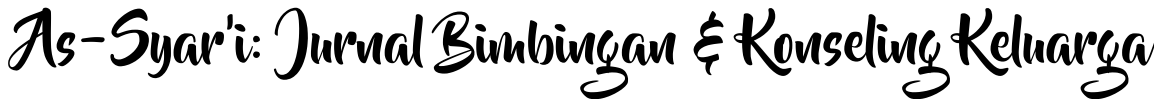

Volume 3 Nomor 1 (2021) 85-94 E-ISSN 2656-8152 P-ISSN 2656-4807

DOI: $10.47476 /$ as.v3i1.305

profesionalismenya dan sekaligus kreativitasnya. Semua itu tentu saja dilakukan atas dasar rasa tanggungjawab dan pengabdiannya yang tinggi pada dunia pendidikan serta keikhlasan dan kecintaannya pada anak- anak didik agar mereka mendapatkan pelayanan yang terbaik. Seperti kutipan Mustafa Kemal Ataturk dalam buku karangan Didik Januari dan Murtafi'atun "Guru yang baik itu ibarat lilin, membakar dirinya sendiri demi menerangi jalan orang lain" (Didik Januari, Murtafiatun, 2019).

\section{METODOLOGI PENELITIAN}

Metode yang digunakan adalah korelasional. Dengan metode korelasional ini dapat diperoleh gambaran sesungguhnya mengenai variabel-variabel penelitian sehingga dapat diketahui hubungan antara dua variabel tersebut, yaitu kreativitas guru PAI (X) dan motivasi belajar siswa (Y). Populasi dalam penelitian ini merupakan keseluruhan subjek penelitian yang akan diperoleh datanya untuk kemudian diproses dalam proses pengolahan dan analisis, yaitu seluruh siswa SMP YPN Bojonggede Bogor dengan jumlah keseluruhan 103 siswa dan sampel dengan jumlah 34\% yaitu sebanyak 35,02 atau dibulatkan menjadi 35 siswa (103x35\%) jumlah seluruh kelas. Peneliti memilih kelas VII dikarenakan sebagai perantara dari kelas VIII dan kelas IX. Pengolahan data dilakukan, langkah selanjutnya yaitu menganalisis data. Dalam penelitian ini, penulis menganalisis menggunakan metode korelasi yang bertujuan untuk menemukan ada tidaknya hubungan dan apabila ada, berapa erat hubungan serta berarti atau tidaknya hubungan itu. Rumus yang digunakan dalam mencari korelasi yaitu rumus korelasi Product Moment. Untuk menguji signifikansi hubungan antara variabel $\mathrm{X}$ dan $\mathrm{Y}$ dengan menggunakan rumusan Thitung. Untuk melihat besarnya pengaruh kreativitas guru pendidikan agama islam terhadap motivasi belajar siswa menggunakan perhitungan koefisien determinasi.

\section{HASIL DAN PEMBAHASAN}

Pengujian hipotesis statistika dalam penelitian ini bertujuan untuk membuktikan ada atau tidak ada hubungan antara variabel $\mathrm{X}$ kreativitas guru pendidikan agama Islam dengan variabel Y motivasi belajar siswa. Pengujian statistika pada penelitian ini meliputi korelasi product moment.

Untuk mengetahui tingkat korelasi antara kreativitas guru pendidikan agama Islam dengan motivasi belajar siswa kelas VII SMP YPN Bojonggede Bogor, maka penulis memasukan data yang diperoleh melalui angket ke dalam tabel di bawah ini.

Setelah data dimasukan ke dalam tabel, kemudian hasil perhitungan tersebut dicari tingkat korelasi variabel X (kreativitas guru pendidikan agama Islam) dengan variabel Y (motivasi belajar siswa) dengan menggunakan rumus uji korelasi Product Moment dengan hasil antara variabel X dan variabel Y diperoleh nilai korelasi yang positif sebesar 0,47.

Berdasarkan hasil data perhitungan dan analisa data yang telah dilakukan, peneliti menginterpretasikan hasil perhitungan dengan menggunakan dua cara sebagai berikut:

1. Interpretasi data secara kasar atau sederhana 


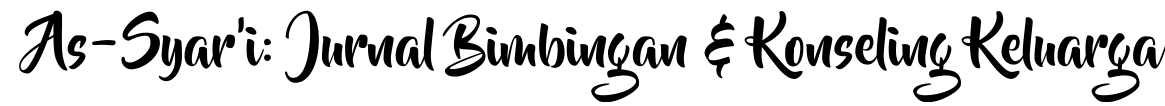

Volume 3 Nomor 1 (2021) 85-94 E-ISSN 2656-8152 P-ISSN 2656-4807

DOI: $10.47476 / a s . v 3 i 1.305$

Pedoman yang digunakan dalam memberikan interpretasi secara sederhana terhadap angka koefisien korelasi Product Moment adalah sebagai berikut

Tabel 4.1

Pedoman Interpretasi Product Moment

\begin{tabular}{|l|l|}
\hline Besarnya "r" Product Moment $(\mathrm{rxy})$ & Interpretasi \\
\hline $0,00-0,20$ & $\begin{array}{l}\text { Antara variabel } \mathrm{X} \text { dan variabel } \mathrm{Y} \text { memang } \\
\text { terdapat korelasi, akan tetapi korelasi itu sangat } \\
\text { lemah atau sangat rendah, sehingga korelasi itu } \\
\text { diabaikan (dianggap tidak ada korelasi antara } \\
\text { variabel } X \text { dan variabel } Y \text { ). }\end{array}$ \\
\hline $0,20-0,40$ & $\begin{array}{l}\text { Antara variabel } X \text { dan variabel } Y \text { terdapat } \\
\text { korelasinyang sangat lemah atau rendah. }\end{array}$ \\
\hline $0,40-0,70$ & $\begin{array}{l}\text { Antara variabel } X \text { dan variabel } Y \text { terdapat } \\
\text { korelasi yang sedang atau cukup }\end{array}$ \\
\hline $0,70-0,90$ & $\begin{array}{l}\text { Antara variabel } X \text { dan Variabel } Y \text { terdapat } \\
\text { korelasi yang kuat atau tinggi. }\end{array}$ \\
\hline $0,90-1,00$ & $\begin{array}{l}\text { Antara variabel } X \text { dan variabel } Y \text { terdapat } \\
\text { korelasi sangat kuat atau sangat tinggi. }\end{array}$ \\
\hline
\end{tabular}

Dari hasil perhitungan yang diperoleh nilai koefisien korelasi 0,47. Jika diperhatikan besarnya rxy sebesar 0,47 ternyata terletak antara 0,40-0,70. Berdasarkan data tersebut, maka dinyatakan bahwa terdapat korelasi atau hubungan yang positif antara kreativitas guru pendidikan agama Islam dengan motivasi belajar siswa kelas VII SMP YPN Bojonggede Bogor dan tergolong korelasi yang sedang atau cukup.

2. Interpretasi dengan menggunakan tabel nilai "r" Product Moment terdapat beberapa langkah yang dilakukan dalam melakukan interpretasi dengan menggunakan tabel nilai "r" Product Moment. Adapun langkahnya sebagai berikut:

Langkah 1: mencari nilai df (Degree of Freedom) atau derajat bebas.

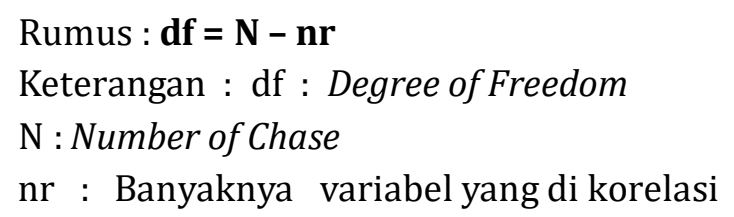

Dalam penelitian ini, sampel yang diambil sebanyak

35 orang siswa kelas VII SMP YPN Bojonggede Bogor, maka $\mathrm{N}=35$ orang, sedangkan variabel yang diteliti sebanyak 2 variabel yaitu kreativitas guru pendidikan agama Islam dengan motivasi belajar siswa, maka $\mathrm{nr}$

$=2$. Dengan demikian diperoleh nilai:

$\mathbf{d f}=\mathbf{N}-\mathbf{n r}$

df $=35-2=33$

Langkah 2 : berkonsultasi pada tabel nilai "r" Product Moment 


\section{As-Syar'i: Jurnal Bimbingan \&̌ Konseling Keluarga}

Volume 3 Nomor 1 (2021) 85-94 E-ISSN 2656-8152 P-ISSN 2656-4807

DOI: $10.47476 /$ as.v3i1.305

Dengan melihat tabel nilai "r" Product Moment, maka dapat diketahui bahwa df sebesar 33 diperoleh "r" Product Moment pada taraf signifikansi

$5 \%=0,344$ dan taraf signifikansi

$1 \%=0,442$.

Langkah 3 : membandingkan besarnya "rxy" dengan "rtabel"

Nilai rxy yang diperoleh yaitu 0,47 sedangkan rtabel masing-masing pada taraf signifikasi $5 \%=0,344$ dan taraf signifikansi $1 \%=0,442$. Hal ini menunjukkan nilai rxy lebih besar dari rtabel baik pada taraf signifikansi $5 \%(0,47>0,344)$, maupun pada taraf signifikansi $1 \%=(0,47>0,442)$.

Dengan demikian maka hipotesis alternatif ( $\mathrm{Ha}$ ) disetujui atau diterima, sedangkan hipotesis nihil (Ho) ditolak. Ini berarti bahwa baik pada taraf signifikansi 5\% ataupun $1 \%$ terdapat korelasi positif yang signifikan antara kreativitas guru pendidikan agama Islam (variabel X) dengan motivasi belajar siswa (variabel Y) kelas VII SMP YPN Bojonggede Bogor.

Interpretasi menggunakan thitung dengan ttabel. Untuk menguji signifikansi hubungan antara variabel $\mathrm{X}$ dan $\mathrm{Y}$ dengan menggunakan rumusan thitung digunakan rumus sebagai berikut: $t$ hitung $=3,0590$. Nilai thitung yang diperoleh yaitu 3,0590 sedangkan ttabel dengan pencarian ttabel pada taraf $5 \%$ :

$2=2,5 \%$ (uji 2 sisi) dengan derajat kebebasan (df) $n-k$ atau

$35-2=33$. Dengan pengujian 2 sisi maka taraf signifikansi adalah $0,025=2,0301$. Hal ini menunjukan nilai thitung lebih besar dari ttabel $(3,0590>$

2,0301). Dengan demikian maka hipotesis alternatif (Ha) disetujui atau diterima, sedangkan hipotesis nihil (Ho) ditolak. Ini berarti bahwa pada taraf signifikansi 0,025 terdapat korelasi positif yang signifikan anatara kreativitas guru pendidikan agama Islam (variabel $\mathrm{X}$ ) dengan motivasi belajar siswa (variabel Y) kelas VII SMP YPN Bojonggede Bogor.

Berdasarkan tabel diatas, maka koefisien korelasi sebesar 0,47 termasuk pada kategori sedang atau cukup. Ada kreativitas guru pendidikan agama Islam dengan motivasi belajar siswa. Untuk menyatakan besar kecilnya pengaruh variabel X dan variabel Y dapat dinyatakan dengan Koefisien Determination.

Rumus : $\mathrm{KD}=(\mathrm{rxy}) 2 \mathrm{x} 100 \%$ Diketahui $: \mathrm{rxy}=0,47$

$\mathrm{KD}=(\mathrm{rxy}) 2 \mathrm{x} 100 \% \mathrm{KD}=(0,47) 2 \times 100 \% \mathrm{KD}=0,2209 \times 100 \% \mathrm{KD}=$

$22,09 \%$

Dari perhitungan diatas ada keterkaitan antara kreativitas guru pendidikan agama Islam dengan motivasi belajar siswa yaitu kreativitas guru pendidikan agama Islam $22,09 \%$ berhubungan dengan motivasi belajar siswa, sedangkan 77,91\% motivasi belajar siswa berhubungan dengan faktor lain, karena keduanya saling berhubungan jika kreativitas guru pendidikan agama Islam yang baik akan dapat mempengaruhi motivasi belajar siswa, begitupun sebaliknya, jika kreativitas guru pendidikan agama Islam itu buruk akan mempengaruhi atau menular pula keburukannya. 


\section{As-Syar'i: Jurnal Binbingan Ė Konseling Keluarga}

Volume 3 Nomor 1 (2021) 85-94 E-ISSN 2656-8152 P-ISSN 2656-4807

DOI: $10.47476 /$ as.v3i1.305

\section{KESIMPULAN}

Berdasarkan uraian yang telah dijelaskan pada bab-bab sebelumnya dan dari hasil penelitian dan pengolahan data tentang "Pengaruh Kreativitas Guru Pendidikan Agama Islam (PAI) Terhadap Motivasi Belajar Siswa Kelas VII SMP YPN Bojonggede Bogor". Maka dapat diambil simpulan sebagai berikut:

Dalam penelitian ini tingkat kreativitas guru pendidikan agama Islam kelas VII di SMP YPN Bojonggede, sangat baik. Hal ini dapat disimpulkan bahwa hasil persentase dari rekapitulasi variabel $\mathrm{X}$ tentang kreativitas guru pendidikan agama Islam yaitu : alternatif jawaban A dengan rata-rata persentase $24,1 \%$, alternatif jawaban $B$ dengan rata-rata persentase $16,8 \%$, alternatif jawaban $C$ dengan rata-rata persentase $14,63 \%$, alternatif jawaban $D$ dengan rata-rata persentase $4,457 \%$. Jumlah jawaban terbanyak adalah pada alternatif A yaitu dengan rata- rata persentase $24,1 \%$ maka dapat disimpulkan kreativitas guru pendidikan agama Islam kelas VII SMP YPN Bojonggede Bogor dikategorikan sangat baik.

Dalam penelitian ini tingkat motivasi belajar siswa kelas VII di SMP $\quad$ YPN Bojonggede, sangat baik. Hal ini dapat disimpulkan bahwa hasil persentase dari rekapitulasi variabel $\mathrm{Y}$ tentang motivasi belajar siswa yaitu : alternatif jawaban A dengan rata-rata persentase $23,543 \%$, alternatif jawaban B dengan rata-rata persentase $12,343 \%$, alternatif jawaban $\mathrm{C}$ dengan rata-rata persentase $16,8 \%$, alternatif jawaban $\mathrm{D}$ dengan rata-rata persentase 3,31429\%. Jumlah jawaban terbanyak adalah pada alternatif A yaitu dengan ratarata persentase $23,543 \%$ maka dapat disimpulkan motivasi belajar siswa kelas VII SMP YPN Bojonggede Bogor dikategorikan sangat baik.

Terdapat hubungan positif yang cukup atau sedang antara Kreativitas Guru Pendidikan Agama Islam (PAI) dengan Motivasi Belajar Siswa Kelas VII SMP YPN Bojonggede Bogor. Hal ini dapat dibuktikan dengan hasil uji korelasi Product Moment, dan interpretasi terhadap rxy dengan mencari df (Degrees of freedom) atau derajat bebas sebagai berikut:

Nilai rxy yaitu 0,47 yang besarnya berkisar antara 0,40-0,70 menunjukkan bahwa terdapat korelasi positif antara variabel $\mathrm{X}$ dengan variabel $\mathrm{Y}$ dan termasuk pada korelasi yang sedang atau cukup. Ini menunjukkan bahwa Pengaruh Kreativitas Guru Pendidikan Agama Islam (PAI) Terhadap Motivasi Belajar Siswa Kelas VII SMP YPN Bojonggede Bogor berada pada level sedang atau cukup. Nilai $\mathrm{df}$ (degrees of freedom) atau derajat bebas sebesar 33 dengan rumus $(\mathrm{df}=\mathrm{N}-\mathrm{nr}=35-2=33)$. Maka df sebesar 33, pada taraf signifikansi $5 \%=0,344$ dan taraf signifikansi $1 \%=0,442$. Hal ini menunjukkan rxy lebih besar dari rtabel baik pada taraf signifikansi $5 \%(0,47>0,344)$, maupun pada taraf signifikansi $1 \%=(0,47>0,442)$. Maka hipotesis alternatif $(\mathrm{Ha})$ diterima dan hipotesis nihil (Ho) ditolak.

Nilai thitung yang diperoleh yaitu 3,0590 sedangkan ttabel dengan pencarian ttabel pada taraf 5\%: $2=2,5 \%$ (uji 2 sisi) dengan derajat kebebasan (df) $n-k$ atau $\quad 35-2=$ 33. Dengan pengujian 2 sisi maka taraf signifikansi adalah $0,025=2,0301$. Hal ini menunjukan nilai thitung lebih besar dari ttabel $(3,0590>2,0301)$. Dengan demikian maka hipotesis alternatif ( $\mathrm{Ha}$ ) disetujui atau diterima, sedangkan hipotesis nihil (Ho) ditolak. Koefisien determinasi sebesar 22,09\% dengan rumus $(\mathrm{KD}=(\mathrm{rxy}) 2 \mathrm{x} 100 \%)$. Maka KD 


\section{As-Syar'i: Jurnal Bimbingan E̊ Konseling Keluarga}

Volume 3 Nomor 1 (2021) 85-94 E-ISSN 2656-8152 P-ISSN 2656-4807

DOI: $10.47476 /$ as.v3i1.305

sebesar 22,09\% dapat dinyatakan bahwa kreativitas guru pendidikan agama Islam $22,09 \%$ berhubungan dengan motivasi belajar siswa, sedangkan 77,91\% motivasi belajar siswa berhubungan dengan faktor lain.

\section{DAFTAR PUSTAKA}

Aksan, Hermawan. 2017. Kamus Bahasa Indonesia Kosakata Lengkap Disertai Pemaknaan Secara Tepat, Bandung: Nuansa Cendikia.

Al-Qur'an dan Terjemah. 2014. Bekasi: Cipta Bagus Segara

Jannah, Miftahul Nur. "Pengaruh Kreativitas Guru Agama dalam Proses Pembelajaran Pendidikan Agama Islam (PAI) terhadap Motivasi Belajar Siswa Kelas VII SMP Negeri 1 Porong Sidoarjo", Skripsi, Surabaya: Jurusan Pendidikan Agama Islam Pada IAIN Sunan Ampel,

2012 .

Januari, Didik. Murtafi'atun. 2019. Trik A-Z Menjadi Guru Kreatif dirindui dan dicintai murid. Temanggung: Desa Pustaka Indonesia.

Mulyasa, E. 2005. Menjadi Guru Profesional. Bandung: PT Remaja Rosdakarya.

Munandar, Utami. 1992.

Mengembangkan Bakat dan Kreativitas Anak sekolah. Jakarta: Gramedia.

Munandar, Utami. 2002. Kreativitas dan Keterbakatan Strategi Mewujudkan Potensi Kreatif dan Bakat. Jakarta: PT Gramedia Pustaka Utama. 


\section{As-Syar'i: Jurnal Bimbingan E̊ Konseling Keluarga}

Volume 3 Nomor 1 (2021) 85-94 E-ISSN 2656-8152 P-ISSN 2656-4807

DOI: $10.47476 /$ as.v3i1.305

Munandar, Utami. 2004. Pengembangan Kreativitas Anak Berbakat. Jakarta:

Rineka Cipta. Purwanto, M. Ngalim. 1985. Psikologi Pendidikan, Bandung : PT.

Remaja Rosdakarya.

Sahertian, Piet. Profil Pendidik Profesional. 1994 Yogyakarta : Andi Offset.

Sardiman. 2006. Interaksi dan Motivasi Belajar Mengajar. Jakarta: PT Raja Grafindo Persada.

Slameto. 1991. Belajar dan Faktor- faktor yang Mempengaruhinya. Jakarta: Rineka Cipta.

Sudijono, Anas. 2014. Pengantar Statistik Pendidikan. Jakarta: PT Raja Grafindo Persada.

Sugiyono, 2019. Metode Penelitian Pendidikan Kuantitatif, Kualitatif, Kombinasi, R\&D dan Penelitian Pendidikan. Bandung: CV. ALFABETA.

Undang-undang Republik Indonesia No. 20 Tahun 2003, tentang Sistem Pendidikan Nasional. Jakarta: Cemerlang.

Usman, Moh. Uzer. 2011. Menjadi Guru Profesional. Bandung: PT Remaja Rosdakarya.

Yusuf, Syamsu dan A Juntika Nurihsan. 2005. Landasan Bimbingan dan Konseling. Bandung: PT Remaja Rosdakarya. 